\title{
edmetic
}

Revista de Educación Mediática y TIC

\section{¿El poder de la gamificación educativa? The power of educational gamification?}

\author{
Verónica Marín-Díaz \\ Universidad de Córdoba (España) \\ vmarin@uco.es
}

La industria del videojuego crece de manera exponencial a lo ancho y largo del planeta. Podría decirse que en estos momentos vive un gran momento de gloria, equiparable a los ya vividos en otras épocas. No obstante, este resurgir viene no solo de la mano del desarrollo que las tecnologías que los producen, sino también por las historias que dentro de ellos se van desarrollando, las cuales llegan a crear sagas, como Final Fantasy, Fifa, Tekken, Final fantasy, Grand Thetft Auto, Metal Solid, The Sims... y así, cientos de temáticas y áreas en las que el ser humano desarrolla su imaginación.

La plasticidad de las nuevas imágenes, la riqueza cromática, el dinamismo y la naturalidad de los movimientos de los personajes, van generando un espacio donde la realidad se confunde con la ficción, hasta el punto de abrir una ventana al aprendizaje de conocimientos, habilidades, competencias, sensaciones y emociones como pocas veces se ha vivido a través del binomio fruto de la unión del videojuego y la educación.

Junto a ellos, los nuevos soportes desde los que se puede acceder a estos, tales como Tablet o Smartphone, se comienza a facilitar el acceso a un mundo que poco o nada tiene en muchas ocasiones que ver con la realidad. Lo que implica, por ejemplo que el juego simbólico, la creatividad y la imaginación, pillares básicos del aprendizaje en la etapa de educación Infantil, tengan un espacio singular de crecimiento.

Debemos de reconocer, que, las nuevas herramientas tales como la Realidad Aumentada o la Virtual, además, otorgan una nueva dimensión a dicho matrimonio, el cual ha sido bautizado como aprendizaje basado en el juego ( $A B J)$ o Game Based Learning (GBL). Recordemos la revolución que supuso el juego Pokemon Go; a nivel mundial se celebraban competiciones 
para «capturen» los pokemons que los Smartphone señalaban estar cerca de nuestra ubicación. En este caso el empleo de la Realidad Virtual transcendió fronteras y creó ¿̇escuela? En el caso de la Realidad Aumentada el videojuego «El secreto de los Arnolfini» (Marín-Díaz, Morales-Díaz y RecheUrbano, 2018) combinan esta tecnología con el acceso a una gymkana digital de aprendizaje de contenidos mediante el uso de la Tablet.

En cualquier caso el «poder» que van tomando los videojuegos ha de ser tenido en cuenta por la comunidad académica. Más allá de los denominados serious games el número de juegos que permiten involucrar el proceso de aprendizaje con uno de ellos es infinito.

En general, todos ellos tienen en común que su objetivo a la hora de su creación y diseño, no era otro más que la diversión y el ocio, pero a pesar de ello, se le pueden otorgar un valor educativo, siempre y cuando nosotros como docentes consideremos que realmente tienen ese «toque» educativo, y que sabemos emplearlo en el aula.

De este modo, encontramos juegos como Animal Crossing, el cual a través de sus diferentes ediciones permite al estudiante de Educación Primaria acercarse al contenido de las materias de Conocimiento del Medio Natural y del Medio Social, así como al de Matemáticas, o Gran Turismo en Secundaria a asignaturas como Historia, Arte, Religión, Matemáticas, Física, Geografía, por citar algunas (Marín, 2011; Marín y Sampedro, 2016) o World of Warcraft (Quesada y Tejedor, 2016, Briceño, Mendoza, Quintero, Malagón y Fonseca, 2017), el cual desarrolla de manera seminconsciente el aprendizaje de contenidos matemáticos complejo,.

Son numerosos los estudios que reflejan las posibilidades de uso de los videojuegos en el aula (del Moral, Guzmán y Fernández, 2018; Marín y Martín, 2014; Marín, 2016; Marín y Sampedro, 2016; Ramos y Botella, 2016) tantas como experiencias en el uso en las aulas de las TIC. Pero aun así, la diferencia entre la «facildad» con las que las segundas se incorporan a las metodologías de clase, y la dificultad con que las primeras lo hacen es sustancial. Quizás, a mi juicio, ello estribe en la desconfianza que generan por los estudios que han reflejado una relación entre ellos y el desarrollo de conductas agresivas (Dorantes, 2017). 
En consecuencia, sí realmente queremos desterrar del universo educativo del videojuego ese halo de negatividad, se debería de incorporar en las metodologías de aula desde los títulos universitarios que conducen a la carrera académica, como pueden ser los títulos de Grado de Educación o el Máster en Enseñanza Secundaria.

Es pues el docente el que debe ver el poder educativo de los videojuegos y que la gamificación forme parte de su vocabulario, pues como señalan del Moral, Guzmán y Fernández (2018) estos pueden ayudar en el desarrollo y consecución de habilidades y competencias, necesarias para la incorporación de la vida activa.

Por tanto la tarea estriba en hacer ver las posibilidades educativas y formativas que los videojuegos no educativos (gamificadores) pueden tener, es por ello necesario una formación en ludificación que ponga en valor este recurso. Pues, seamos sinceros, todos hemos jugado a videojuegos, porque nos lo creamos o no jugar a través de una Tablet es hacerlo con un videojuego llámese APP o videojuego, se han creado con el mismo fin, el entretenimiento, entonces, ¿̇por qué pueden entretener pero no educar?

Si analizamos las metodologías de aprendizaje de la etapa de Educación infantil, el juego pivota en todo el sistema de enseñanza, es por ello que, bien pueden ser extrapolado a otros niveles académicos o contextos educativos. No obstante, la historia del jideojuego siempre se escribirá en función de la experiencia, creencias y visiones que los profesores tengan de ellos.

$$
\text { O... ¿̇no? }
$$

\section{Referencias}

BRICEÑO, W., MENDOZA, N., QUINTERO, J., MALAGÓN, S., y FONSECA, F. (2017). El videojuego como herramienta de representación. Un análisis espacial y cultural de World of Warcraft. LifePlay: Revista académica internacional sobre videojuegos, 6, 82-96. Recuperado de http://www.lifeplay.es/volumen6/Dossier/084 WILBELYS\%20B.\%20ET\%20AL Manuscrito\%2084-95.pdf

DEL MORAL, E., GUZMÁN, A.P., y FERNÁNDEZ, L.C. (2018). Game-Based Learning: Increasing the Logical-Mathematical, Naturalistic, and 
Linguistic Learning Levels of Primary School Students. NAER, Journal of New Approaches in Educational Research, 7(1), 31-39. doi: $10.7821 /$ naer.2018.1.248

DORANTES, G. (2017). El uso prolongado de videojuegos violentos influye en la percepción de la violencia de adultos jóvenes. PSIENCIA. Revista Latinoamericana de Ciencia Psicológica, 9(2). doi: http://dx.doi.org/10.5872/psciencia.v9i2.217

MARÍN, V (2011). La perspectiva educativa de los videojuegos. Una realidad tangible. Revista Conecta2, 2 (II), 63-79. Recuperado de http://www.revistaconecta2.com.mx/Archivos/ll_EDICION/2 3.pdf

MARÍN, V. (2016). ¿Hay posibilidades de trabajar la inclusión a través de los videojuegos? Revista del Salomé, 1 (2), 67-87

MARÍN, V., Y MARTíN, J. (2014). ¿Podemos utilizar los videojuegos para el desarrollo del currículo de la etapa de infantil? NAER, Journal of New Approaches in Educational Research, 3(1), 20-25. doi: 10.7821/naer.3.1.20-25

MARÍN, V., y SAMPEDRO, B.E. (2016). Innovando en el aula de Educación Primaria con GT 6. International Journal of Technology and Educational Innovation, 2(1), 13-19. Recuperado de http://revistas.uma.es/index.php/innoeduca/article/view/1061/1870

MARIN-DÍAZ, V., MORALES-DÍAZ, M., \& RECHE-URBANO, E. (2018). Posibilidades educativas de los videojuegos en la etapa de Primaria según los maestros en formación. Estudio de caso. NAER, Journal of New Approaches in Educational Research, En prensa.

QUESADA, A., Y TEJEDOR, S. (2016). Aplicaciones educativas de los videojuegos: el caso de World of Warcraft. Pixel-Bit: Revista de Medios y Educación, 48, 187-196. doi:10.12795/pixelbit.2016.148.12

RAMOS, S., y BOTELLA, A.M. (2016). La integración del videojuego educativo con el folklore. Una propuesta de aplicación en Educación Primaria. Revista Electrónica Interuniversitaria de Formación del Profesorado, 19(3), 1 15-121. doi: http://dx.doi.org/10.6018/reifop.19.3.267581 